\title{
BILATERAL BRANCHING CONTRIBUTES MINIMALLY TO THE ENHANCED IPSILATERAL PROJECTION IN MONOCULAR SYRIAN GOLDEN HAMSTERS ${ }^{1}$
}

\author{
KAREN HSIAO
}

Department of Psychology, Massachusetts Institute of Technology, Cambridge, Massachusetts 02139

Received February 23, 1982; Revised August 17, 1983; Accepted September 21, 1983

\begin{abstract}
Studies of the plasticity of retinal projections following neonatal eye ablations in rats and hamsters have demonstrated an enhanced ipsilateral projection which affects both the terminal fields and the number of ipsilaterally projecting cells. The enhancement has been attributed to an excess of bilateral branching by single optic nerve axons, but this claim was not supported by the present study. Double retrograde labels were used to quantify the ipsilateral enhancement and measure the extent of bilateral branching in hamsters with neonatal eye removals. In 19 normal Syrian golden hamster retinas the average number of bilaterally projecting retinal ganglion cells (BPRGCs) was $7.4(\mathrm{SD}=3$ ), and the average number of ipsilaterally projecting retinal ganglion cells (IPRGCs) was 1349 ( $\mathrm{SD}=478$ ) (Hsiao, K., G. M. Sachs, and G. E. Schneider (1984) J. Neurosci. 4: 359-367). In nine retinas of hamsters with removal of one eye at birth, the average number of BPRGCs was 25.3 ( $\mathrm{SD}=9.2$ ), and the average number of IPRGCs per retina was 2036 $(\mathrm{SD}=414)$. Although the increase in BPRGCs is statistically significant, it accounted for only 2 to $3 \%$ of the $51 \%$ increase in the number of IPRGCs. Various possible mechanisms underlying the formation of the enhanced projection are enumerated, and it is concluded that the predominant mechanism is a reduction of cell death in the developing population of IPRGCs.

The responses of IPRGCs and BPRGCs to early eye enucleations were also examined with respect to age at enucleation and cell size. No difference in size was found between IPRGCs and BPRGCs in monocular hamsters compared to normal hamsters. The critical ages for the ipsilateral enhancement following early eye removals were determined and compared for IPRGCs and BPRGCs. The critical age for IPRGCs occurred before eye opening, and the critical age for BPRGCs occurred a few days after eye opening. These facts, taken together with the large difference between the fractional increases in numbers of these two types of cells following early eye removals, led to the conclusion that, in addition to a reduction in cell death (accounting for the enhanced number of IPRGCs), there is another phenomenon which accounts for the enhanced number of BPRGCs.
\end{abstract}

When investigators first noticed that neonatal, unilateral eye enucleations in rabbits, rats, and hamsters produced an enhanced ipsilateral projection field, this ablation paradigm became regarded as one that was particularly useful in perturbing the balance of cues necessary for normal optic fiber development (Chow et al., 1973; Lund et al., 1973; Schneider, 1973). Since then, the effect has been analyzed in detail, and studies have demonstrated both an enhancement of the ipsilateral terminal field and an increase in the number of ipsilaterally pro-

${ }^{1}$ This work was supported by National Institutes of Health Grants 2R01-EY-00126 and 5P30-EY-02621 and by the Insurance Medical Scientist Scholarship Fund. I wish to thank Michel Kliot and Douglas Hess for discussions, and Gerald Schneider for suggestions, advice, and support. jecting retinal ganglion cells (IPRGCs) (Dräger and Olsen, 1979; Finlay et al., 1979; Lund et al., 1980; Jen and Lund, 1981). Several mechanisms could produce these changes: $(a)$ postoperative growth of collaterals by contralaterally projecting fibers, $(b)$ increased retention of bilaterally branched axons present early in development, (c) reduction in cell death during development in a population of bilaterally projecting cells, $(d)$ reduction of cell death during development in a population of ipsilaterally projecting cells, $(e)$ retention of only ipsilateral branches of bifurcating bilaterally projecting optic axons, $(f)$ diversion of contralaterally destined fibers, or $(g)$ excessive proliferation of ipsilaterally projecting cells.

This paper presents a study using a double retrograde labeling method, described in the previous paper (Hsiao et al., 1984), to quantify the ipsilateral enhancement in 
Syrian golden hamsters and measure the extent to which bilateral branching contributes to its formation. It thus distinguishes mechanisms $a, b$, and $c$ from mechanisms $d, e, f$, and $g$. Information is also provided on critical ages and on changes in cell size in enucleated animals. A brief report of the major findings has already appeared (Hsiao and Schneider, 1980).

\section{Materials and Methods}

The procedures for application of tracers (horseradish peroxidase or Nuclear Yellow), histology, and numerical, topographical, and morphometric analyses were described in the previous paper (Hsiao et al., 1984). To produce monocular hamsters, the left or right eye was removed under hypothermic anesthesia in 9 pups within the first $24 \mathrm{hr}$ after birth (day 0 ) and, under hypothermic, ether, or Chloropent (Fort Dodge Laboratories) anesthesia in 45 pups between 1 and 32 days after birth. The hamsters used for these studies are listed in Table I. The gestational period for Syrian golden hamsters is $15^{2 / 3}$ to 16 days. All hamsters were raised in a colony where the daily dark period of $10 \mathrm{hr}$ began at 3:30 P.M. Their eyes could be gently opened on day 15 without damaging lid tissue, and their eyes opened spontaneously by day 16 . Animals at least 8 weeks old were used for anatomical studies of the retina.

Three 10-week-old hamsters underwent acute, unilateral eye removals 7 to 10 days before application of tracers to control for the possibility that eye removal

TABLE I

Schedule of early eye removals in experimental cases on which study of age-related effects is based

\begin{tabular}{|c|c|c|}
\hline $\begin{array}{c}\text { Age at Eye Removal } \\
\text { (days) }\end{array}$ & $\begin{array}{l}\text { No. of Cases Success- } \\
\text { fully Analyzed in Adult- } \\
\text { hood }\end{array}$ & $\begin{array}{l}\text { No. of Cases per Time } \\
\text { Interval }\end{array}$ \\
\hline 0 & 9 & 9 \\
\hline 1 & 1 & \\
\hline 2 & 1 & 6 \\
\hline 3 & 1 & \\
\hline 4 & 3 & \\
\hline 5 & 1 & \\
\hline 6 & 2 & \\
\hline 7 & 1 & 6 \\
\hline 8 & 2 & \\
\hline 9 & 4 & \\
\hline 10 & 3 & \\
\hline 11 & 0 & 8 \\
\hline 12 & 1 & \\
\hline 13 & 2 & \\
\hline 14 & 2 & \\
\hline 15 & 3 & 8 \\
\hline 16 & 1 & \\
\hline 17 & 6 & \\
\hline 18 & 3 & \\
\hline 19 & 0 & 9 \\
\hline 20 & 0 & \\
\hline 21 & 4 & \\
\hline 22 & 0 & \\
\hline 23 & 0 & 4 \\
\hline 24 & 0 & \\
\hline $28-32$ & 4 & 4 \\
\hline Total & 54 & 54 \\
\hline
\end{tabular}

alone could alter the kinetics of tracer activity or transport. However, neither the mean number of bilaterally projecting retinal ganglion cells (BPRGCs), 7.3 (SD = 5), nor that of IPRGCs, 1093 ( $\mathrm{SD}=250$ ), was statistically different from those in two-eyed hamsters, satisfactorily demonstrating that eye removal per se did not alter labeling kinetics.

\section{Results}

\section{Hamsters with unilateral eye removals on day 0}

Quantities. Table II summarizes the data concerning cell quantities. The mean number of IPRGCs in nine monocular hamster retinas was $2036(\mathrm{SD}=414)$ cells, which represented a statistically significant $(p<0.01)$ $51 \%$ increase over the normal number (mean, 1349; SD $=478$, for 19 normal hamster retinas). The mean number of BPRGCs in the monocular hamster retinas was 25.3 $(\mathrm{SD}=9.2)$ cells, which represented a statistically significant $(p<0.01) 242 \%$ increase over $7.4(\mathrm{SD}=3.0)$ cells, the mean number of BPRGCs in the normal hamster retinas. Thus, only 2 to $3 \%$ of the $51 \%$ increase in the number of IPRGCs, or 17.9 of 687 cells, were bilaterally branching cells.

The mean number of ectopic IPRGCs (defined as ipsilaterally projecting ganglion cells located outside of the ventrotemporal crescent; see Hsiao et al., 1984) in monocular hamster retinas was $409(\mathrm{SD}=188)$ cells, which represented a statistically significant $(p<0.05)$ $98 \%$ increase over $207(\mathrm{SD}=65)$ cells, the mean number of ectopically located IPRGCs in normal hamster retinas. However, ectopically located IPRGCs constituted only $29 \%$ of the cells in the enhanced ipsilateral projection, the remaining $71 \%$ arising from cells located within the

TABLE II

Quantity of ipsilaterally and bilaterally projecting cells in normal hamsters and hamsters made monocular at birth

A comparison of the number of IPRGCs and BPRGCs in normal and monocular hamsters is made using normalized numerical values. The number of IPRGCs in the temporal crescent was inferred from the difference in the total number of IPRGCs and the number of ectopic IPRGCs. The enhanced projection was defined with respect to the number of IPRGCs in normal hamsters (Hsiao et al., 1984). The relative contributions to the enhanced projection of IPRGCs located in the temporal crescent and in ectopic positions are presented as percentages. These data show that the enhanced ipsilateral projection is primarily composed of unilaterally projecting cells arising from the temporal crescent.

\begin{tabular}{|c|c|c|c|}
\hline $\begin{array}{c}\text { Cell } \\
\text { Population }\end{array}$ & $\begin{array}{c}\text { Normal } \\
\text { Hamsters }\end{array}$ & $\begin{array}{l}\text { Monocular } \\
\text { Hamsters }\end{array}$ & $\begin{array}{l}\text { Enhanced } \\
\text { Projection }\end{array}$ \\
\hline $\begin{array}{l}\text { Total number of } \\
\text { IPRGCs }\end{array}$ & $\begin{aligned} n & =19 \\
\text { mean } & =1349 \\
\mathrm{SD} & =478\end{aligned}$ & $\begin{aligned} n & =9 \\
\text { mean } & =2036 \\
\mathrm{SD} & =414\end{aligned}$ & $2036-1349=687$ \\
\hline $\begin{array}{l}\text { Number of ec- } \\
\text { topic IPRGCs }\end{array}$ & $\begin{aligned} n & =13 \\
\text { mean } & =207 \\
\mathrm{SD} & =65\end{aligned}$ & $\begin{aligned} n & =7 \\
\text { mean } & =409 \\
\mathrm{SD} & =188\end{aligned}$ & $\begin{array}{c}409-207=202 \\
=29 \% \text { of } 687\end{array}$ \\
\hline $\begin{array}{l}\text { Number of } \\
\text { IPRGCs in } \\
\text { temporal cres- } \\
\text { cent }\end{array}$ & mean $=1142$ & mean $=1627$ & $\begin{array}{c}1627-1142=485 \\
=71 \% \text { of } 687\end{array}$ \\
\hline $\begin{array}{l}\text { Total number of } \\
\text { BPRGCs }\end{array}$ & $\begin{aligned} n & =19 \\
\text { mean } & =7.4 \\
\mathrm{SD} & =3.0\end{aligned}$ & $\begin{aligned} n & =9 \\
\text { mean } & =25.3 \\
\mathrm{SD} & =9.2\end{aligned}$ & $\begin{array}{c}25.3-7.4=17.9 \\
=2.6 \% \text { of } 687\end{array}$ \\
\hline
\end{tabular}


temporal crescent. In summary, cells of the enhanced ipsilateral projection originated predominantly within the temporal crescent and projected unilaterally.

Locations. Table III summarizes the data concerning cell locations. Figure 1 illustrates the locations of doubly labeled retinal ganglion cells in five representative retinas from monocular hamsters. As in normal hamster retinas, a disproportionately large number of doubly labeled cells was located in the outer $35^{\circ}$ of the retina; $80 \%$ (121 of 152 ) of all doubly labeled cells were located in this annulus, which constituted $56 \%$ of the entire retinal area. Also similar to that seen in normal hamster retinas was the finding that the upper sector contributed the largest proportion of doubly labeled cells.

The cells comprising the enhanced ipsilateral projection arose preferentially from within the temporal crescent $(71 \%)$, but no such preference was observed for the enhanced bilateral projection because BPRGCs increased in roughly uniform fashion inside $(250 \%)$ and outside $(210 \%)$ the temporal crescent. It follows that the enhanced bilateral projection arose mainly from outside the temporal crescent $(66 \%)$ in rough correspondence to the fractional retinal area there $(81 \%)$.

Sizes. Table IV summarizes the data concerning cell sizes. As in normal hamster retinas, the largest BPRGCs were found in the upper sector, the smallest in the nasal sector. There was no statistically significant difference in the sizes of IPRGCs or BPRGCs between monocular and normal hamsters.

Increases in average cell diameters of $4 \mu \mathrm{m}$ have been reported for IPRGCs in rats following early eye removals (Lund et al., 1980). Such large increases should have been detectable in the hamster retinas, even despite histological variability, but were not observed.

\section{Unilateral eye removals performed along a time continuum}

To ascertain the critical age for the enhanced formation of BPRGCs and IPRGCs in response to early eye

TABLE III

Retinal distribution of doubly labeled cells in normal hamsters and hamsters rendered monocular at birth

A comparison of the retinal distribution of doubly labeled cells (DLCs) in 19 normal and 9 monocular hamsters illustrates the similarity of their distributions.

\begin{tabular}{|c|c|c|c|c|c|}
\hline \multirow{2}{*}{ Region of Retina } & \multirow{2}{*}{$\begin{array}{l}\text { Percentage } \\
\text { of Retinal } \\
\text { Area }\end{array}$} & \multicolumn{2}{|c|}{ Normal Hamsters } & \multicolumn{2}{|c|}{$\begin{array}{l}\text { Monocular Ham- } \\
\text { sters }\end{array}$} \\
\hline & & $\begin{array}{l}\text { No. of } \\
\text { DICs }\end{array}$ & $\begin{array}{c}\% \text { of all } \\
\text { DICs }\end{array}$ & $\begin{array}{l}\text { No. of } \\
\text { DICs }\end{array}$ & $\begin{array}{c}\text { \% of all } \\
\text { DICs }\end{array}$ \\
\hline Outer $35^{\circ}$ annulus & $56 \%$ & 81 & $82 \%$ & 121 & $80 \%$ \\
\hline Inner $69^{\circ}$ disc & $44 \%$ & 18 & $18 \%$ & 31 & $20 \%$ \\
\hline Upper hemisphere & $50 \%$ & 80 & $81 \%$ & 105 & $69 \%$ \\
\hline Lower hemisphere & $50 \%$ & 19 & $19 \%$ & 46 & $31 \%$ \\
\hline \multicolumn{6}{|l|}{ Upper sector } \\
\hline Entire & $33 \%$ & 51 & $52 \%$ & 65 & $43 \%$ \\
\hline Outer $35^{\circ}$ & $19 \%$ & 46 & $46 \%$ & 56 & $37 \%$ \\
\hline \multicolumn{6}{|l|}{ Temporal sector } \\
\hline Entire & $33 \%$ & 36 & $36 \%$ & 62 & $41 \%$ \\
\hline Outer $35^{\circ}$ & $19 \%$ & 31 & $31 \%$ & 51 & $34 \%$ \\
\hline \multicolumn{6}{|l|}{ Nasal sector } \\
\hline Entire & $33 \%$ & 12 & $12 \%$ & 25 & $16 \%$ \\
\hline Outer $35^{\circ}$ & $19 \%$ & 4 & $4 \%$ & 14 & $9 \%$ \\
\hline
\end{tabular}
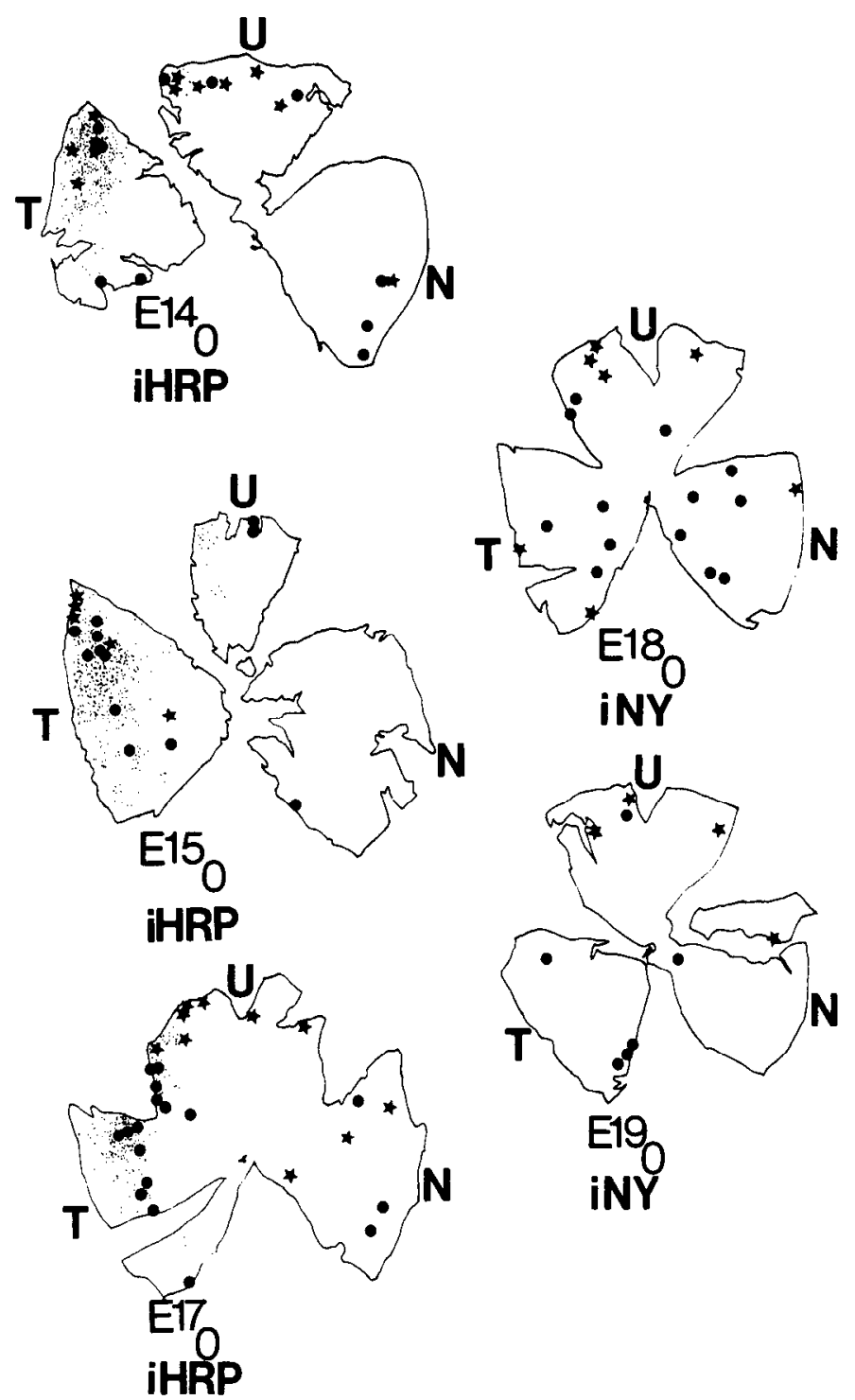

Figure 1. Doubly labeled cells in five representative flatmounted retinas from hamsters rendered monocular at birth. The symbols $i H R P$ and $i N Y$ beneath each retina indicate whether the retina was situated ipsilateral to the HRP or Nuclear Yellow application site, respectively. In the retinas ipsilateral to the HRP injection site, some of the IPRGCs in the temporal crescent are indicated by small dots. $U$, upper; $N$, nasal; $T$, temporal. The positions of doubly labeled cells are indicated by either stars or large dots in the same manner as described previously (Hsiao et al., 1984).

removals, eye enucleations in hamster pups were performed along a time continuum ranging from postnatal day 0 to day 32 (Table I), and the numbers of BPRGCs and IPRGCs were determined in the adult. The results indicate that hamsters in which eye removals were performed on or up to day 18 sustained at least a 2 -fold increase in the number of BPRGCs, but hamsters with eye removals performed on day 21 possessed a normal number of BPRGCs (Fig. 2). The critical age was defined as the first day on which eye removal resulted in a mean which was less than 1 standard deviation from the norm. The critical age for the response of BPRGCs to early eye removals occurred between days 18 and 21 . The number 
TABLE IV

Retinal ganglion cell sizes in normal hamsters and hamsters rendered monocular at birth

The sizes of IPRGCs and BPRGCs for normal and monocular hamsters are compared. In some cases (*), eye ablations were performed between days 28 and 32 , which is after the critical period. For that reason, these were classified as normal hamsters. These data reveal that no significant difference was found in the sizes of IPRGCs of the temporal crescent, ectopic IPRGCs, or BPRGCs between these two groups of hamsters $(0.1<p<0.2$ for all three comparisons).

\begin{tabular}{|c|c|c|c|c|c|c|c|c|}
\hline \multirow{2}{*}{$\begin{array}{l}\text { Type of Retinal } \\
\text { Ganglion Cell }\end{array}$} & \multicolumn{4}{|c|}{ Normal Hamsters } & \multicolumn{4}{|c|}{ Monocular Hamsters } \\
\hline & Case & $\begin{array}{c}\text { No. of cells } \\
\text { (cases) }\end{array}$ & $\begin{array}{c}\text { Median cell size } \\
(\mu \mathrm{m})\end{array}$ & $\mathrm{SD}$ & Case & $\begin{array}{l}\text { No. of cells } \\
\text { (cases) }\end{array}$ & $\begin{array}{l}\text { Median cell size } \\
(\mu \mathrm{m})\end{array}$ & $\mathrm{sD}$ \\
\hline IPRGCs & N36 & 143 & 11.2 & 2.1 & & & & \\
\hline \multirow[t]{2}{*}{ Crescent } & N41 & 135 & 11.8 & 2.4 & $\mathbf{E} 22$ & 199 & 12.1 & 2.8 \\
\hline & $\mathrm{N} 42$ & 118 & 12.8 & 3.0 & $\mathbf{E} 24$ & 149 & 12.4 & 2.8 \\
\hline \multirow[t]{2}{*}{ Ectopic } & $\mathrm{E} 3^{*}$ & 67 & 11.1 & 2.2 & $\mathrm{E} 22$ & 108 & 12.1 & 2.6 \\
\hline & $\mathrm{E} 4^{*}$ & 54 & 9.8 & 1.8 & E24 & 151 & 11.2 & 1.8 \\
\hline Aggregate & & $(\mathrm{N}=3)$ & 10.53 & 0.67 & & $(\mathrm{~N}=2)$ & 11.65 & 0.64 \\
\hline BPRGCs (aggregate) & & $(\mathrm{N}=19)$ & 11.63 & 1.95 & & $(\mathrm{~N}=9)$ & 12.18 & 1.47 \\
\hline Upper sector & & 51 & 11.75 & 2.7 & & 65 & 12.6 & 2.8 \\
\hline Temporal sector & & 36 & 11.25 & 2.8 & & 62 & 11.8 & 3.1 \\
\hline
\end{tabular}

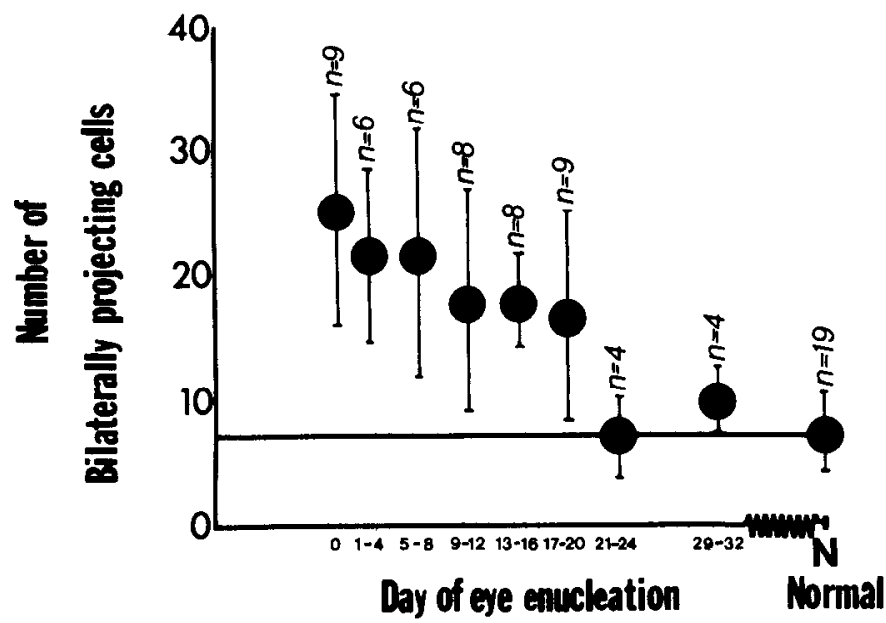

Figure 2. How the age at which an eye is removed affects the number of bilaterally projecting cells in adult hamsters. Normalized values were used in this graph. The mean and standard deviation of the number of cells at each time interval are represented by solid circles flanked by vertical line segments. The number of cases per time interval is indicated above each point (see Table I). The critical age was defined as the earliest time interval in which the mean number of cells differed from the normal mean by less than a standard deviation. For BPRGCs, this occurred between day 18 and day 21 .

of IPRGCs also diminished as eye removals were performed in older infants (Fig. 3). The most rapid decline occurred in subjects with eye removals performed toward the end of the first week of life. The critical age for the response of IPRGCs to early eye removals occurred by days 13 to 16 .

The pattern of decline in the number of bilaterally and ipsilaterally projecting retinal ganglion cells with increasing age at eye ablation differed for these two kinds of cells. The number of IPRGCs declined gradually, but the number of BPRGCs exhibited a sharp decline just before day 21 .

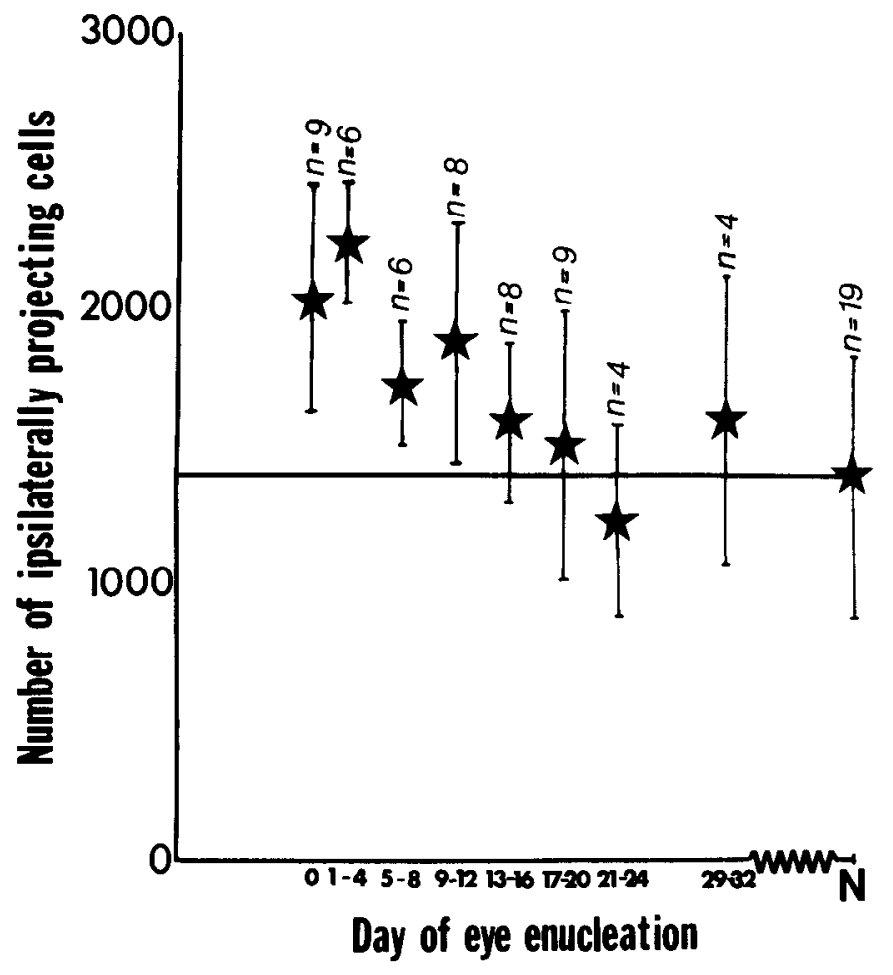

Figure 3 . How the age at which an eye is removed affects the number of ipsilaterally projecting cells in adult hamsters. Normalized values were used in this graph. The mean and standard deviation of the number of cells at each time interval are represented by stars flanked by vertical line segments. The number of cases per time interval is indicated above each point. The critical age was defined as the earliest time interval in which the mean number of cells differed from the normal mean by less than a standard deviation. For IPRGCs, this occurred between day 13 and day 16 .

\section{Discussion}

The principal finding of this study is that bilaterally branching optic fibers constitute only 2 to $3 \%$ of the 
enhanced ipsilateral projection in hamsters with neonatal eye removals. This result differs from the conclusion reached by Cunningham (1976) after a study of rats with neonatal removal of one eye. He had applied cobalt chloride to the optic tract contralateral to the remaining eye, and reported that it "appeared to fill all" of the axons in the opposite tract, interpreting this to mean that the enhanced ipsilateral projection was principally composed of branched optic axons. Species differences probably cannot account for this discrepancy since Jeffery and Perry (1981), using a double-labeling method, reported a paucity of bilaterally projecting cells contributing to the enhanced ipsilateral projection in monocular rats. Cunningham (1976) may have failed to adequately consider the role of non-optic pathways which travel in or along both optic tracts and cross at the midline at or near the optic chiasm in the commissure of Gudden described nearly a century ago (Ramon y Cajal, 1909).

With some exceptions, the findings presented here for the hamster are in accord with those of Jeffery and Perry (1981) for the rat, regarding the quantities of IPRGCs and BPRGCs in normal and monocular subjects (see also Jeffery et al., 1981). Such evidence lends support for a theory involving a reduction in cell death in the remaining eye of monocular subjects. Data on retinal ganglion cell death have been provided by Sengelaub and Finlay (1981), who showed that diminished rates of cell death in the temporal part of the remaining retina of infant monocular hamsters could account for the increment in the number of IPRGCs observed in adulthood. However, these authors were unaware of the difficulties in interpreting Cunningham's (1976) results and could not distinguish between cell death in unilaterally versus bilaterally projecting cells. It is now possible to argue with greater certainty that the enhanced ipsilateral projection arises primarily as a consequence of a reduction of cell death in a population of IPRGCs.

The rates of cell death in the retina demonstrated by Sengelaub and Finlay (1981) correspond remarkably well with the data presented in this paper concerning the effect of age at enucleation on the number of IPRGCs observed in adulthood. From the cell death data, a maximum decline in the number of IPRGCs seen in the adult would be expected to occur in subjects with eye removals between days 4 and 6 , and the critical age would be expected to occur soon after day 12 . This is precisely what was found.

In addition to a reduction in cell death, we must consider a possibility discussed in the previous paper (Hsiao et al., 1984), namely, the survival of the ipsilateral axon from ganglion cells which early in development had bilaterally projecting axons (mechanism $e$ in the introduction). However, the low number of ectopically located IPRGCs indicates that the errancy rate at the chiasm is very low. This implies that the number of BPRGCs early in development would have to be extremely high to account for more than a small percentage of the increased IPRGCs by the additional mechanism.

Studies of the development of retinal projections in Syrian hamsters have shown that the trajectory of the optic tract is determined prenatally, while the innerva- tion of its various terminal regions is principally a postnatal event (Frost et al., 1979; Jhaveri et al., 1983). Both crossed and uncrossed retinofugal axons are present in the optic tract at birth, but the development of the uncrossed axons lags slightly behind the development of the crossed axons. The establishment of the adult distributions of the retinofugal projections is completed prior to eye opening, and includes the segregation of the projections of the two eyes in regions where optic axons terminate in precise retinotopic order. The studies presented here of the effects of eye removal performed at different ages demonstrated that the period of plasticity of the ipsilateral projection includes the period in which the segregation of the projections of the two eyes is established, and corresponds well with the time course of retinal ganglion cell death, all of which occur prior to eye opening.

The plasticity of BPRGCs extends a few days beyond eye opening, however, which is evidence that another mechanism exists. The occurrence of an additional phenomenon is further supported by the disparity in the proportional increases in cell numbers following early eye removal for ipsilaterally and bilaterally projecting cells (51\% for IPRGCs and $242 \%$ for BPRGCs). The removal of one eye early in development may either reduce competition at terminal fields sufficiently to enhance axon survival in bilaterally projecting cells, or induce sprouting at the chiasm. In line with the former is the evidence in the neonatal rat for an excess of optic nerve axons compared to retinal ganglion cells, suggesting that developing retinal axons give rise to branches within the nerve (Lam et al., 1982; Potts et al., 1982).

Increases in cell size could not be detected for either BPRGCs or IPRGCs in hamsters with early eye removals. Lund et al. (1980) found a substantial increase in cell size in the retinotectal cells of rats with early eye removals, as did Dräger and Olsen (1979) in the retinal ganglion cells of monocular mice. I can explain this discrepancy only by suggesting that it reflects species differences, or statistical errors.

An issue of primary significance concerns the segregation of ipsilaterally and contralaterally projecting fibers. The experiments presented here address this problem in the following manner: Had there been a tendency for developing axons to project bilaterally, then early removal of one eye should have enhanced the retention and subsequent detection of their collaterals. However, since this was not apparently the case, it appears instead that developing axons, with only a small number of exceptions, project unilaterally. It is not known whether developing fibers are pre-committed in some fashion to one particular laterality.

It is known, however, that in ontogeny, ipsilateral fibers lag behind contralateral fibers (Currie and Cowan, 1974; Frost et al., 1979; Stone et al., 1980). These two groups of fibers differ in other ways as well. IPRGCs are larger than contralaterally projected retinal ganglion cells (CPRGCs) in all three classes of cat retinal ganglion cells (Stone et al., 1980; Wässle and Illing, 1980), in Galago retinal ganglion cells (DeBruyn et al., 1980), and in retinal ganglion cells of several rodents (Dräger and 
Olsen, 1979; Lund et al., 1980; Hsiao et al., 1984). The IPRGCs and CPRGCs of the W type in cats have different electrophysiological properties (Stone and Fukuda, 1974). The decussation pattern of cat $W$ cells and rodent retinal ganglion cells is similar, with cells of both lateralities overlapping in the temporal retina (Fukuda and Stone, 1974). It is not known whether electrophysiological properties of rodent ganglion cells differ by laterality. In Rana pipiens, the ipsilateral retinal projection terminates only in the thalamus and the contralateral projection terminates in both the midbrain and thalamus (Currie and Cowan, 1974). Lastly, it is well known that the ipsilaterally and contralaterally projecting fibers terminate in separate layers of the lateral geniculate nucleus and superior colliculus. Thus, the laterality of a cell is also associated with specific characteristics of the cell's morphometry, electrophysiology, and central projections.

It is difficult to envision how laterality could confer on a cell its particular properties, since there is no evidence that cells behave differently on one side of the brain versus the other. Studies of the synaptic patterns of anomalously crossed projections in hamsters (Finlay et al., 1979) and prawns (Friedlander and Levinthal, 1982), for example, suggest that when cells err in laterality, they maintain their original specificity of synaptic connectivity. Therefore, rather than suppose that laterality confers to a cell its particular properties, it seems more likely that a fiber is in some fashion pre-committed along with other characteristics to its particular laterality. The paucity of bilaterally projecting fibers, both in normal and monocular subjects, supports the notion of unilateral commitment but does not address the question of when or how this would occur. This notion can also be applied toward understanding the origin of ectopic IPRGCs which, based on morphometry, resemble anomalously uncrossed CPRGCs.

\section{References}

Chow, K. L., L. H. Mathers, and P. D. Spear (1973) Spreading of uncrossed retinal projections in superior colliculus of neonatal enucleated rabbits. J. Comp. Neurol. 151: 307-322.

Cunningham, T. J. (1976) Early eye removal; produces excessive bilateral branching in rat: Application of cobalt filling method. Science 194: 857-859.

Currie, J., and W. M. Cowan (1974) Evidence for the late development of the uncrossed retinothalamic projections in the frog, Rana pipiens. Brain Res. 71: 133-139.

DeBruyn, E. J., V. L. Wise, and V. A. Casagrande (1980) The size and topographic arrangement of retinal ganglion cells in the galago. Vision Res. 20: 315-327.

Dräger, U. C., and J. F. Olsen (1979) Retinofugal projections in pigmented, albino, and one-eyed mice. Soc. Neurosci. Abstr. 5: 783.

Finlay, B. L., K. G. Wilson, and G. E. Schneider (1979) Anomalous ipsilateral retinotectal projections in Syrian hamsters with early lesions: Topography and functional capacity. J.
Comp. Neurol. 183: 721-740.

Friedlander, D. R., and C. Levinthal (1982) Anomalous anatomy of identified neurons in the larval prawn: Spontaneous and induced by microlesions. J. Neurosci. 2: 121-142.

Frost, D. O., K. -F. So, and G. E. Schneider (1979) Postnatal development of retinal projections in Syrian hamsters: A study using autoradiographic and anterograde degeneration techniques. Neuroscience 4: 1649-1677.

Fukuda, Y., and J. Stone (1974) Retinal distribution and central projections of $\mathrm{Y}-, \mathrm{X}-$, and $\mathrm{W}$-cells of the cat's retina. J. Neurophysiol. 37: 749-772.

Hsiao, K., and G. Schneider (1980) The effect of early unilateral eye enucleation on bilaterally projecting retinal ganglion cells in hamsters. Soc. Neurosci. Abstr. 6: 684.

Hsiao, K., G. M. Sachs, and G. E. Schneider (1984) A minute fraction of Syrian golden hamster retinal ganglion cells project bilaterally. J. Neurosci. 4: 359-367.

Jeffery, G., and H. Perry (1981) Evidence for ganglion cell death during development of the ipsilateral retinal projection in the rat. Dev. Brain Res. 2: 176-180.

Jeffery, G., A. Cowey, and H. G. J. M. Kuypers (1981) Bifurcating retinal ganglion cell axons in the rat, demonstrated by retrograde double labelling. Exp. Brain Res. 44: 34-40.

Jen, L. S., and R. D. Lund (1981) Experimentally induced enlargement of the uncrossed retinotectal pathway in rats. Brain Res. 211: 37-57.

Jhaveri, S., M. A. Edwards, and G. E. Schneider (1983) Two stages of growth during development of the hamster's optic tract. Anat. Rec. 205: 225A.

Lam, K., J. Sefton, and M. R. Bennett (1982) Loss of axons from the optic nerve of the rat during early postnatal development. Dev. Brain Res. 3: 487-491.

Lund, R. D., T. J. Cunningham, and J. S. Lund (1973) Modified optic projections after unilateral eye removal in young rats. Brain Behav. Evol. 8: 51-72.

Lund, R. D., P. D. Land, and J. Boles (1980) Normal and abnormal uncrossed retinotectal pathways in rats: An HRP study in adults. J. Comp. Neurol. 189: 711-720.

Potts, R. A., B. Dreher, and M. R. Bennett (1982) The loss of ganglion cells in the developing retina of the rat. Dev. Brain Res. 3: 481-486.

Ramon y Cajal, S. (1909) Histologie du Systeme Nerveux de l'Homme et des Vertebrés, p. 44, Consejo Superior de Investigaciones Cientificas, Instituto Ramon y Cajal, Madrid, 1972 reprint.

Schneider, G. E. (1973) Early lesions of superior colliculus: Factors affecting the formation of abnormal retinal projections. Brain Behav. Evol. 8: 73-109.

Sengelaub, D. R., and B. L. Finlay (1981) Early removal of one eye reduces normally occurring cell death in the remaining eye. Science 213: 573-574.

Stone, J., and Y. Fukuda (1974) Properties of cat retinal ganglion cells: A comparison of W-cells with X-and Y-cells. J. Neurophysiol. 37: 722-748.

Stone, J., A. Leventhal, C. R. R. Watson, J. Keens, and R. Clarke (1980) Gradients between nasal and temporal areas of the cat retina in the properties of retinal ganglion cells. J. Comp. Neurol. 192: 219-233.

Wässle, H., and R. -B. Illing (1980) The retinal projection to the superior colliculus in the cat: A quantitative study with HRP. J. Comp. Neurol. 190: 333-356. 